\title{
I klemme mellem Indien og Kina
}

Jørgen Ørstrøm Møller

En relativt let tilgængelig fremstilling, der kan anbefales enhver med interesse i ikke alene Sydøstasien, men i hvordan små lande klemt mellem stormagter må udfolde adræthed i deres udenrigsog sikkerhedspolitik

Asad-ul Iqbal Latif: Between Rising

Powers: China, Singapore and India. Institute of Southeast Asian Studies, ISEAS, Singapore, 2007.

Igennem de seneste år er interessen for udviklingen i Asien steget næsten eksplosivt. Den har koncentreret sig om Kina og Indien i kraft af disse landes økonomiske tyngde og dermed stigende politiske indflydelse. Set fra omverdenen er temaet om Kina eller Indien eller et samspil og samarbejde mellem disse to lande det absolut toneangivende.

Set med asiatiske øjne er der imidlertid et helt andet tema, der tiltager sig megen stor interesse, nemlig hvorledes disse to giganters fremmarch på scenen berører resten af Asien herunder navnlig de små lande.
Indtil omkring 1990 var Asien et i sikkerhedspolitisk henseende stabilt område med tre kendte flashpunkter: Den koreanske halvø, Taiwan og Indien-Pakistan. De sydøstasiatiske lande levede i fred, sikkerhed og stabilitet, beskyttet, selv om de ikke brød sig om dette ord, af den amerikanske militære tilstedeværelse. De havde deres egne konflikter, som fra tid til anden brød ud i massemedierne og affødte politiske udfald; men ingen anså dem for så alvorlige, at de kunne true stabiliteten - og det gjorde de heller ikke.

De sydøstasiatiske lande levede lykkeligt uden at være konfronteret med det virkeligt store spil i stormagternes stræben efter indflydelse og interessesfære. Japan gjorde sig gældende med økonomisk indflydel- 
se, men søgte ikke politisk og slet ikke militær indflydelse.

\section{Billedet efter 1990}

Efter 1990 med Kinas økonomiske vækst, gradvise indtræden i den globale økonomi og dermed stigende ønske om politisk indflydelse, ikke mindst gennem permanent medlemskab af FN's Sikkerhedsråd, har dette billede ændret sig fundamentalt. Nu er alle de sydøstasiatiske lande stillet over for udfordringen om fastlæggelse af en udenrigspolitik, der tager højde for Kinas voksende magt, Indiens efterfølgende indtræden og den etablerede stormagt USA.

Det er ikke nogen let ligning, der skal løses. USA har i mange år velsignet udviklingen i Sydøstasien og opnået megen good will og kredit gennem sin rolle som stabiliseringsmagt. Det er fortsat verdens ubestridt mægtigste magt, men USA ligger langt væk, dets økonomiske betydning for Sydøstasien er aftagende, medens det modsatte gør sig galdende for Kina. Dertil kommer, at USA igennem de sidste år tilsyneladende ikke tildeler Sydøstasien den betydning, som landene i området mener sig berettiget til. Ved gentagne møder herunder på topniveau og udenrigsministerniveau har USA glimret ved afbud eller deltagelse på lavere niveau.

Dilemmaet for de sydøstasiatiske lande er således, at prognoser og fremskrivninger alle peger på Kina og sikkert også Indien som de vigtigste magter for området i fremtiden, men endnu ikke overstråler USA. Det er ikke nogen overraskelse, at det må og bør afstedkomme et tyngdeskift i de sydøstasiatiske landes udenrigs- og sikkerhedspolitik med stigende opmærksomhed koncentreret om Kina og Indien og mindre vægt til USA.

Dilemmaet forstærkes af, at de på samme måde som de mindre europæiske lande ikke ønsker at blive alt for afhængige af nærtliggende stormagter. Danmark har i århundreder ført udenrigspolitik under overskriften 'ikke for afhængig af Tyskland'.

For de sydøstasiatiske lande gælder dette diktum for Kina. I realiteten er der flere bolde i luften nemlig den falmende stormagt USA, Japan som ikke reelt har formået at etablere sig som en politisk modvægt over for Kina, Kina, der efter langt de flestes opfattelse kommer til at dominere Asien på godt og ondt, samt Indien, der synes at være det mest realistiske bud på en modvægt til Kina uanset, at mange herunder undertegnede ser udviklingen under overskriften Kina og Indien i stedet for Kina eller Indien.

Dette udenrigs- og sikkerhedspolitiske net af problemer, udfordringer og risici er det overordnede emne for Asad-ul Iqbal Latifs bog 'Between Rising Powers', der netop er udgivet af Institute of Southeast Asian Studies i Singapore. 


\section{LITTERATUR}

\section{Sydøstasiens traditionelle rolle}

Bogens udgangspunkt er Sydøstasiens traditionelle rolle som et område, hvor mange og forskellige religioner og racer har slået sig ned. Allerede før det trettende århundrede kom jøder, arabere og persere fra det mellemøstlige område til Sydøstasien. Købmænd og handelsfolk fra Kina og Indien fulgte efter.

Verdens store religioner og civilisationer hinduisme, buddhisme, islam og kristendom er alle repræsenteret i Sydøstasien. I det nittende århundrede blev området, bortset fra Thailand, koloniseret af hollændere, briter og franskmænd, der alle i forvejen havde slået sig ned som handelsfolk og trådt i fodsporet på portugiserne.

Det er således et område, der muligvis ikke tiltvinger sig stor interesse i en traditionel udenrigs- og sikkerhedspolitisk samt strategisk analyse med indflydelsessfære, strid om territorier osv.; men det er i høj grad et område, som er af vital betydning for den drejning sikkerhedspolitikken har taget igennem de seneste år. Nu peger pilen på potentielle konflikter og konfrontationer mellem yderligtgående grupper inden for religioner med påstand om, at de har ret til at påtvinge andre grupper deres opfattelse, og hvis ikke det lykkes da gribe til voldelige skridt. Dette spil er på tavlen for Sydøstasien.

Singapore er i centrum som et lil- le geografisk område med mindre end 4 millioner singaporeanere. Landet er på størrelse med Bornholm, men her findes etniske kinesere, malayer, indere og europæere plus buddhisme, islam, hinduisme, kristendom, taoisme, konfucianisme, den jødiske tro og adskillige andre religioner.

Det er lykkedes for Singapore at opretholde ro mellem disse forskellige befolkningsgrupper, hvad der i sig selv er bemærkelsesværdigt, i kraft af de potentielle konflikter ikke mindst affødt af, at Singapore med et flertal af etniske kinesere er omgivet af Indonesien og Malaysia med et flertal af malayer.

\section{Singapores balancegang}

Den singaporeanske udenrigs- og sikkerhedspolitik er præget af balancegang mellem de stormagter, som har indflydelse i området.

I de første årtier efter Singapores selvstændighed (1965) blev landet navnlig af Kina betragtet som en amerikansk allieret med meget dårlige bilaterale forhold til følge. Kina søgte at destabilisere Sydøstasien herunder Singapore med undergravende skridt. Først da Deng Xiaoping sad fast i sadlen i begyndelsen af 1980'erne blev kursen lagt om.

$\mathrm{Nu}$ fik Singapore til gengæld en vigtig rolle, som lad os kalde det formidler og fortolker til det nye Kina, der slog ind på kurs mod markedsøkonomi, og i den lille bystat så mu- 
ligheder for at lære af andres erfaringer uden frygt for misbrug. Der er næppe tvivl om, at bag kulisserne har Singapore spillet en væsentlig rolle som intellektuel sparringspartner for Kina og været et sted, hvor det i starten utvivlsomt usikre Kina kunne prøve ideer og tanker af med sikkerhed for, at eventuelle fejltrin ikke blev misbrugt eller førte til andre uønskelige konsekvenser.

Senere er Indien kommet til. Selv om Singapores rolle over for dette land ikke har haft samme karakter som over for Kina, har Singapore i et vist omfang også kunnet bruges som sparringspartner og selv ønsket at påtage sig denne rolle.

Asad-ul Iqbar Latifs bog er en re- lativt let tilgængelig fremstilling af disse til tider komplekse problemer. Han er velbevandret i emnet og skriver med en let og elegant pen ikke mindst takket være sin fortid som journalist.

Bogen kan anbefales på det varmeste for enhver med interesse $\mathrm{i}$ ikke alene Sydøstasien; men hvorledes små lande klemt mellem stormagter under skiftende omstændigheder må udfolde adræthed i deres udenrigs- og sikkerhedspolitik, med den viden, at fejltrin kan vise sig kostbare.

Jørgen Ørstrøm Mфller, Visiting Senior Research Fellow, ISEAS og Adjungeret Professor, Copenhagen Business School. 